\title{
Aneurysm Indicator
}

National Cancer Institute

\section{Source}

National Cancer Institute. Aneurysm Indicator. NCI Thesaurus. Code C139038.

An indication as to whether there is the presence of an aneurysm. 